\title{
OBITUARY: Professor Alessandro Stucchi
}

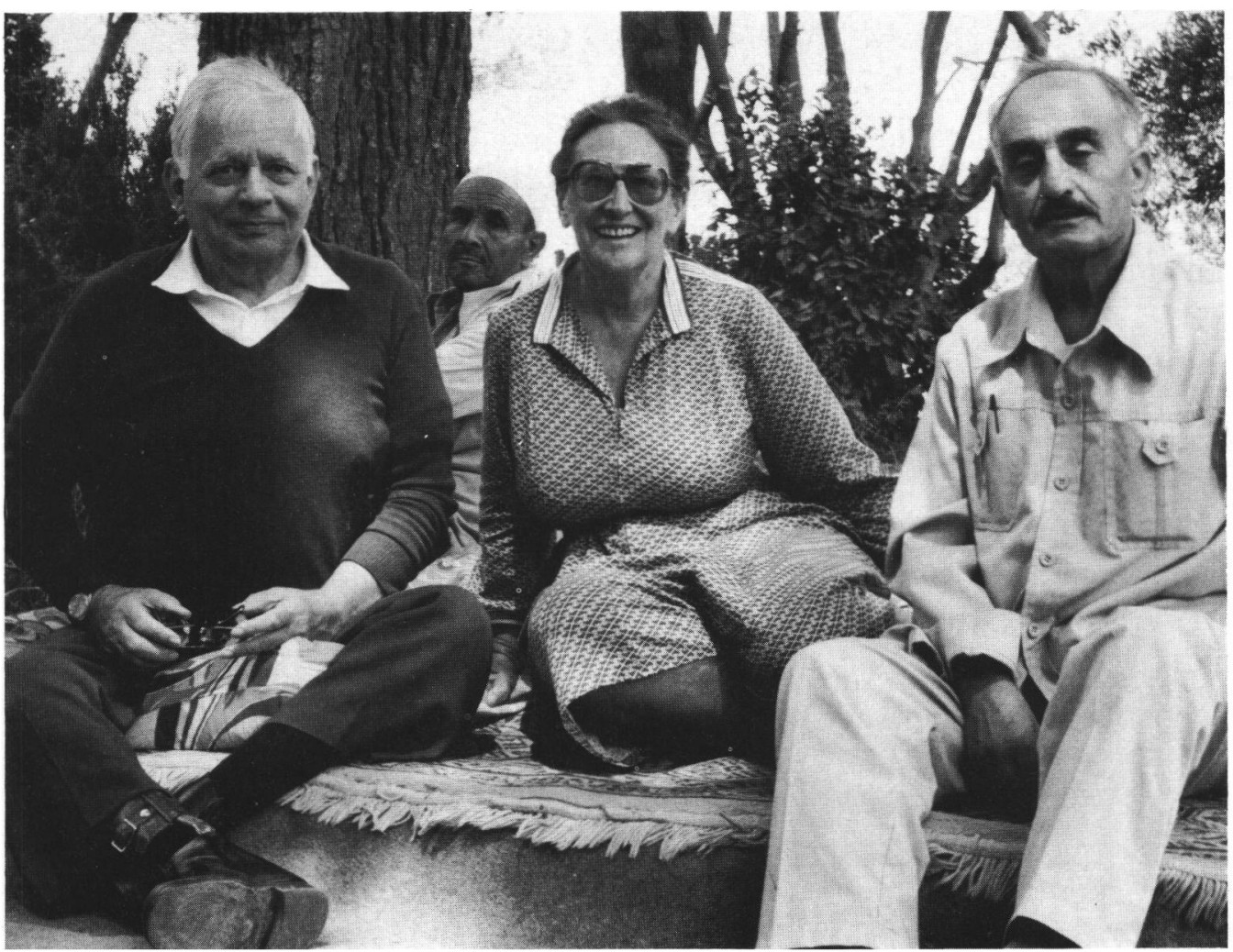

Sandro Stucchi (left) with Joyce Reynolds and Breyek Atiyah at Shahat in 1988, enjoying a party organised by the Department of Antiquities at Cyrene.

The death of Professor Alessandro Stucchi - Sandro Stucchi - in July of 1991 - has inflicted a very sad and serious loss on Cyrenaican archaeology. Director of the Italian Archaeological Mission to Cyrene since its inception in 1957 and also in charge of the restoration of the Severan Arch at Leptis Magna from 1970, he was, over nearly thirty-five years, an outstanding leader in the field and an embodiment of the high qualities of his country's archaeological tradition. His boyish figure, seriously lamed by poliomyelitis contracted in his childhood (but he was so indomitable that one easily forgot it) and his alert face, often lit by a smile and still young for his age when I last saw him in autumn 1990, are unforgettable features in the picture of post-war Cyrene; while his work there has transformed our knowledge of the Greek city and, in part, of its Roman successor too.

He was born in 1922, at Gorizia on the frontier of Italy and Yugoslavia - and his earliest published work was a record of the then-surviving monuments of the neighbouring town of Friuli (Forum Julii) which saved from oblivion a number that have now been destroyed. He was a university student at Milan and a graduate student in the Italian archaeological schools of Rome and of Athens, in the latter coming under the important influence of Professor Doro Levi. With this training it is not surprising that he was, at heart, an art historian; but he fully appreciated the value of stratigraphic excavation and sought to combine the two disciplines in his fieldwork. 
He was throughout his life an astonishingly hard and systematic worker. By 1957 when he began his regular seasons in Cyrene he was also an Inspector in the Italian State Archaeological Service at Ancona and Professor of Archaeology and Art History as well as Director of the Archaeological Institute at Urbino - a formidable load. During university sessions it involved a weekly round from his home in Rome to Ancona, on to Urbino and back to Rome, in the early days by slow and inconvenient trains (expertae credite, I once travelled with him for part of the journey). From then onwards he also spent several months each summer living in comparatively simple conditions at Shahat, with much rough terrain to walk over and long working hours. His life was no doubt easier after 1976 when he moved from the Chair and the Institute at Urbino to a Chair and the Directorship of the Archaeological Institute at Rome (La Sapienza); but always there were many time-consuming administrative chores, both in Italy and Libya, which he seemed to take in his stride (although we sometimes shared a relaxing and half-humorous grumble about them). Nevertheless he immediately launched a series of vigorous campaigns on the unpublished pre-war excavations in Cyrene's Agora, which he later extended to other parts of the site, notably to the Gymnasium, the Caesareum, the Temple of Zeus (which he was in process of restoring) and, most recently, the Sanctuary of Apollo.

He brought to all that he did high intelligence, sensitive perception with great learning, and a remarkable flair for finding talented assistants. In time more and more of these came from among his own pupils in Urbino, proof of his powers as a teacher which were grounded in lucidity of mind and a visible love of archaeology which could not fail to stimulate.

The range of his research is also remarkable. At Cyrene and elsewhere in Cyrenaica he attacked matter from the prehistoric to the Byzantine and was developing an interest in the Islamic too; outside Cyrenaica his serious studies included discussions of optical illusion in the Olympia pediments, the Delphic charioteer, the ephebe of Motya, the Riace bronzes, Trajan's Column; and his interests went much further, as a comparatively recent visit that he made to China shows. In all he undertook his careful analyses of what was visible and planned explorations of what was not brought order and new insights to confused issues. The main results for Cyrenaica are to be seen in the volumes of L'Agorà di Cirene (several in part or in whole by others, but all stemming from his inspiration); and more of these are on the way. Other important subjects he considered in articles, many of them in Quaderni di Archeologia della Libia, sometimes with immediately convincing solutions, sometimes proposing views that have proved distinctly controversial (as especially those on links between pre-Greek Cyrene and the Mycenaean world). There is also his volume L'Architettura Cirenaica, written at a moment when modern developments began to pose new threats to Libyan antiquities - an ambitious catalogue raisonné of all the known Cyrenaican monumental structures, grouped chronologically and typologically to give an overview of the architectural history of the territory. It was urgent that this record should be compiled and published; and, as he once told me, there seemed (after R. G. Goodchild's death) no-one to do it but himself - so he expended great effort and risked his arm on an enterprise in which, inevitably, there was much interpretative detail with which others disagreed. I think that he recognised the inevitability of this - although he was certainly disappointed at the extent of the disagreements expressed in reviews. The achievement is nonetheless real and the book is and will continue to be fundamental reading for all who work in Cyrenaica.

He undertook much and certainly pushed himself very hard, so that it is not surprising that sometimes a certain tenseness was apparent in him; but he would relax with friends. He established a particularly good relationship with R. G. Goodchild, to whom his annual visits to Cyrene brought welcome opportunities for detailed and lively interchange on the monuments that they both loved. They tried out their ideas on each other, each modifying 
and refining as they talked, in a most fruitful way. After Goodchild's death there was noone outside Italy so continuously available to him for similar sessions, although he had good relationships with the members of the Libyan Department of Antiquities at Shahat and of the several other foreign groups working in Cyrenaica. To all of us he was a hospitable and most generous friend in need - offering me in the early days transport to out of the way places, including, on holidays, beauty spots, and giving all manner of other practical help (I have 'borrowed' from him flour, buckets, basins, fruit and even water at need). And he was very open in talking of his new discoveries with us.

He still held his Chair at Rome at his death but when the Rome Institute was converted into the Dipartimento di Scienza dell' Antichità his directorship lapsed. He was a full fellow of the Pontifical Academy of Archaeology, a corresponding fellow of the Academy of the Lincei, and a corresponding member of the German Archaeological Institute. He leaves an assured reputation both for his own research and for his creation in the Italian Mission to Cyrene of an organisation with high academic standards and zeal to carry on. For me there is particular pleasure as well as poignancy in the recollection of his sparkling eyes as he brought out from his office in Shahat in 1990 a sweet-smelling root and a plant stem with umbels, a silphium plant just rediscovered after centuries of assumed extinction by a joint expedition of the Libyan Department of Antiquities and the Italian mission. For the Society there will be satisfaction that the Council's invitation to him to lecture in London in 1992 gave him real pleasure although by the time that he received it he knew that he could not accept it.

Joyce Reynolds

The Society is grieved to hear of the recent death of Professor Martin Harrison who, amongst his other achievements, worked in Cyrenaica, particularly on the early Christian churches, and was a Council Member of the Society between 1984 and 1988. An obituary will appear in the next issue of Libyan Studies. 